\title{
Exploration and Practice of Application-based Undergraduate Electronic Information Majors Training Mode in Dalian Nationalities University
}

\author{
Min $\mathrm{Li}^{1, \mathrm{a}}$, Shuang $\mathrm{Xu}^{2, \mathrm{~b}}$, Ying $\mathrm{Xiao}^{3, \mathrm{c}}$ and Junxing Zhang ${ }^{4, \mathrm{~d}}$ \\ ${ }^{1,2,3,4}$ Information \& Communication Engineering, Dalian Nationalities University, China

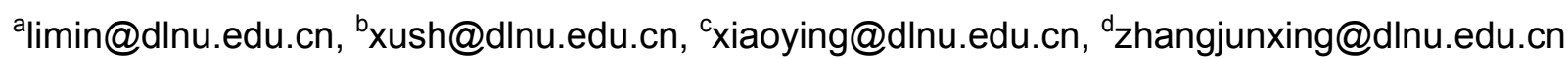

Keywords: Training Mode; Application-based Undergraduate; Electronic Information Majors

\begin{abstract}
The paper proposes the idea of 3 type engineers (skilled, product development \& project implementation, research) in application-based undergraduate electronic information majors. Combined with engineering education accreditation standards, the paper explores and practices it from the training standard and curriculum matrix, teaching contents and methods, practice teaching, teaching group, quality monitoring and evaluation, etc. The good results have achieved.
\end{abstract}

\section{Introduction}

Chinese higher education has been transformed from elite to mass. Particularly undergraduate education is entering a new period of development and facing new challenges. The challenge focuses on two aspects, improving of quality and classification of development, in order to meet the evolving needs of society for diverse talent. These two aspects link closely and reinforce mutually. At the present stage, the number of undergraduate students in the application-oriented university is the majority of the national university undergraduate scale and application-oriented talents training has become the focus on the development of these Universities. Applied undergraduate talents education reform is a social system engineering, involving all aspects, both internal resistance, but also external constraints. China joined the "Washington Agreement" in 2013, that marks China's engineering education and quality assurance has made major strides and points out the direction for application-oriented undergraduate talents training reform. It also improves the level of internationalization and the quality of talents training about China's higher engineering education continuously. Taking electronic information majors of Dalian Nationalities University as a case, the paper explores the application-oriented talent training mode reform in electronic information majors and has some enlightenment to the teaching reform of other application-oriented universities relevant professional.

\section{Application-based Undergraduate Training Problems from the Employment Point of View}

There are two reasons to cause the difficulties of graduates' employment from reflection on education. One is students' concept of employment. So called difficulties are largely upon the ideas of ideal employment and jobs for graduates are not low judging from the actual market demand. Another is university training mode. From the recruitment perspective, employers really need people, but want to recruit experienced staff. They think that graduates have unrealistic expectations and poor practical application. A survey of 12,398 graduates has been published in China Education Daily and the results show: $79 \%$ of people believe that they cannot learn something useful in the university, $77 \%$ that what they learned is out of touch with reality and $80 \%$ that the university curriculum and teaching content are not dissatisfactory. In the surveyed graduates, a considerable part graduated from application-based undergraduate universities [1]. University education is closed in past system and talents training cannot keep up with the change and development of times tightly. Graduates have gone through four years of study, have a great deal of theoretical knowledge, but do not have the ability needed for business. So application-based talents training reform is exactly to make the specific and practical education normalization, to have graduates really apply their knowledge and effectively enhance their employability. 


\section{Build Application-based Undergraduate Electronic Information Majors Training Mode}

Establish "3 Type Engineer" Training Concept of Electronic Information Majors. A survey of graduate employment during last five years conducted by Dalian Nationalities University among electronic information majors [2]. The types of graduate employment are divided into three categories, $\mathrm{R} \& \mathrm{D}$, engineering application, postgraduate and abroad. Where, the proportion of graduates engaged in engineering application reached about $60 \%, \mathrm{R} \& \mathrm{D}$ about $15 \%$, postgraduate and abroad about $15 \%$. Moreover through visiting to enterprises, employers reflect the lack of the basic ability and quality in current information majors graduates. $44.0 \%$ of employers believe that graduates employed lacks of a scientific attitude and spirit (such as rigorous and meticulous attitude, dare to doubt, criticism and the courage to innovative spirit, etc.), $40.2 \%$ believe their lacks of project awareness (such as economic management, ethics and moral, etc.) and innovation consciousness, $38.0 \%$ believe their identifying and solving engineering problems not very well. In addition, a substantial proportion of employers believe that graduates cannot use technology and modern tools necessary for engineering practice flexibly, operate test as well as analyze and explain the data proficiently, independent work ability is not strong, language and text communication capability is weak, the quality of lifelong learning is poor and the active learning enthusiasm is not sustained.

Through the above investigation and research, the undergraduate training types of electronic information majors can be determined as $\mathrm{R} \& \mathrm{D}$, engineering application, postgraduate and abroad, in which, $R \& D$ and engineering application are the main direction of training mode. How to adapt to industry demand for basic ability and quality of graduates is the starting and ending points of talents training and directly related to the quality of future engineers. Therefore, we proposed the talents training concept of 3 Type Engineers (skilled, product development \& project implementation, research) in electronic information majors to meet the needs of informational industry and solve the technical problems in the first production lines.

Develop Training Programs According to the Types. In developing the programs, there's a need to properly handle the relationship between knowledge structure and ability structure. Knowledge structure is the basic framework of the program and ability structure the body and the core reflected by the program. The two is a relationship of interdependence and how to further strengthen the training of ability is the important contents in consideration of reforming training programs [3]. The program can be determined according to training types and China's engineering education accreditation criteria. The following points need attention.

For Skilled Engineers. It's necessary to increase the practical aspects and improve the practical application ability through experimental center, training base and other practical education platforms to do project management, engineering internship and project integrated design.

For Engineers of Product Development \& Project Implementation. To strengthen cooperation with enterprises and promote studio courses through learning by doing and industry-university cooperation teaching mode are required to achieve talents training with business or industrial projects and form the training mode of serving China's strategies and social special needs.

For Research Engineers. To implement the cooperation with research institutes is needed to introduce research projects into the studio. Through the learning with problem-based, project-based, design-based, students' preliminary scientific research ability is cultivated and the training mode of the discipline and major integration is formed.

Reform Teaching Content, Teaching pattern and method. According to the programs developed, there must be some corresponding changes in the contents, patterns and methods of teaching.

Firstly, Emphasis on Student-centered. Increase the elective areas, through elective mechanisms to achieve distinction in the teaching content, and thus the individualized, the student-centered and output-oriented (goal-oriented) education orientation are achieved. Self-study courses, discussion class, design class, research courses, engineering training courses, business courses, race courses and other ability curriculum are opened, so that students' abilities of engineering design and course knowledge application are enhanced. 
Secondly, Reinforcement in Research and Construction of Course Group. Course group is the basic unit of the relevant curriculum system, scientific construction of course group is the fundamental guarantee in achieving training objectives [4]. The course group construction during training applied talents is to highlight ability training requirements based on major objectives, divide some relatively independent but closely linked courses into a number of course units in line with the logical links between courses and the relationship with entire curriculum system and training objectives, and then build logical teaching content system through science division and integration of contents, points and objectives related to the internal courses.

Color figures are welcome for the online version of the journal. Generally, these figures will be reduced to black and white for the print version.

Finally, Responsibility and Level of Teachers. Teachers must be clear that their course will help students which aspects of knowledge and ability, and play what role in students' entire knowledge structure. They should implement different teaching methods in different training stages to meet students' cognitive characteristics, meanwhile guide the students to turn to the self-learning pattern, such as "learn by doing", "learning to do" and "do the thinking", "thinking to do".

Strengthen Practice. Practice teaching is different from theory teaching in the essential characteristics. Practice teaching conducts teaching activities in practice, students are always inseparable from the practice mode [5]. In original "Phased, multi-level, multi-mode, modular, integrated, open" engineering education practice teaching system, single course experiments will be appropriately combined into a comprehensive experiment of many courses, studio courses will be incorporated into the teaching plans, the teaching mode of business-based practice projects will be carried out relying on companies, Additional electronic engineers, embedded engineers and other professional qualification training courses will be open to students. Students can choose business part-time teachers to instruct the graduation topics of engineering projects and complete the graduation projects in companies. The educational environment of an organic combination of inside and outside the classroom formed and improved the project quality enhancement.

Build Excellent Teaching Team. According to the "3 type engineers" training objectives, training standards and training system, guided by engineering education accreditation standards, the teaching teams were built based on skills, product development $\&$ project implementation and research. The teaching team structure of "outstanding leader + course group teachers + business mentors + foreign teachers" is used [6]. The team members are divided into academic and application-oriented, meanwhile members with business or related experience in engineering practice should be more than $20 \%$. The academic members must focus on training scientific research ability in addition to professional theory curriculum teaching, undertake scientific research work to ensure the team's academic level and ability, so the team's research, development and teaching can grow continuously. The application-oriented members are mainly responsible for experiment and practice courses, in charge of training the students' engineering background and engineering capabilities. They must have not only a solid theoretical foundation but also a wealth of practical experience, especially engineering backgrounds. Some engineering and technical personnel, advanced operation skilled personnel, management personnel with extensive experience in engineering practice and teaching ability from well-known universities and companies at home and abroad should be hired as part-time teachers. The part-time teachers must participate undergraduate teaching such as academic lectures, graduation design and production practice guidance. Business mentors and foreign teachers can not only sufficiently meet demand of improving the teaching level, but also bring new ideas and the latest development information of the industry. They are the extension and supplement for course group teaching staff.

Establish System of Teaching Quality Monitoring and Talent Training quality Evaluation. Normality of assessment and evaluation is the basis of continuous improving talent training. A variety of evaluation mechanism need to be established and completed for tracking and process evaluations of students throughout the learning process. Teaching quality monitoring should be transformed gradually into monitoring of knowledge and ability students acquired from classroom teaching quality. Something must be made in building talent training quality evaluation system, such 
as the combination between subjective evaluation and objective evaluation, between process evaluation and result evaluation, among school evaluation, business evaluation and social evaluation. The evaluation should be varied from different talent training types. The employment rate is important for training quality evaluation of skilled-based talents. For the type of product development and project implementation, the evaluation of training quality should pay attention to the quality of employment on the basis of the employment rate. The rates of postgraduate and abroad should be emphasized for the research-based talent training quality evaluation. A complete set of long-term effective mechanism of monitoring student recruitment, learning process and employment should be established to correspond the educational continuous improvement purpose of the engineering education accreditation standards, to contribute to promoting application-oriented talent training.

\section{Conclusion}

"3 type engineers" talent training mode reform were started between majors of electronic information engineering and communications engineering of Dalian Nationalities University in 2009. All of the students in these two majors benefit from it. Students' abilities in employment, engineering practice and innovation have significantly enhanced. The employment rate of graduate is more than $90 \%$. Students issued more than 40 papers and obtained more than 100 patents under the guidance of teachers. "Build a diversified engineering talent training system, enhance students' ability of engineering practice overall" from Dalian Nationalities University won the second prize on the undergraduate teaching achievements of Liaoning Province general higher education in 2012. The two majors of electronic information engineering and communications engineering in Dalian Nationalities University ranked second respectively in the undergraduate major comprehensive evaluation among colleges and universities of Liaoning Province in 2013 [7].

\section{Acknowledgements}

This work was financially supported by both of Liaoning Higher Education Teaching Reform Projects (UPRP20140172, UPRP20140259).

\section{References}

[1] Commentator of the periodical. Application-based Talent Training: Adjustment of Higher Education Goals. Research in Educational Development. No.5 (2009), p.1

[2] M. Li, J. Zhang and X. Chen. Students' Employment Explore in Information Majors of Colleges and Universities. Educator. No.6 (2010), p.17-19

[3] D. Zhou and L. Mo. Problems of the Application-based Talent Training Program Reform in Local Colleges and Universities. Modern Education Management. No.3 (2011), p. 63-67

[4] X. Yang. The Mode of Practical Management Talent Training in Local Universities: Four Shifts. Journal of Yangzhou University (Higher Education Study Edition). Vol.15, N0.1 (2011), p. 3-7

[5] F. Liu and S. Wang. Construction and Implementation of Higher Education Practice Teaching Mode. Modern Education Management. No.3 (2011), p. 88-90

[6] M. Li, Y. Xiao, J. Zhang and S. Xu. Teaching Team Construction of Electronic Information Majors based on Engineering Education Accreditation. Educator. No.5 (2015), p. 14-16

[7] Information on http://www.upln.cn/html/2014/Column_0103_0128/2469.html 